\title{
WHY SMART LEADERS ARE IMPORTANT IN SMART CITY DEVELOPMENT - A CONCEPTUAL FRAMEWORK
}

\author{
Chun Jung Yue Daniel ${ }^{1}$, Nabsiah Abdul Wahid ${ }^{1}$ and Cheng Ling Tan ${ }^{1}$ \\ ${ }^{1}$ Graduate School of Business, Universiti Sains Malaysia, Penang, Malaysia
}

\begin{abstract}
The aim of this paper is to discuss the role of leadership attributes and activities play on the alliance firm performance in smart city developments. It also highlights an overview of the growing phenomena in the smart city and sustainability development. This paper suggests the importance for business leaders to actively volunteer and lead alliance firm in promoting the smart city and sustainability development through organizing various activities to seek for new business growth. The paper provides a leadership perspective to evaluate non-profit alliance firm in smart city and sustainability development. This justifies the importance of leadership attributes and activities towards the non-profit alliance firm performance and a conceptual framework has been presented. It provides a highly original look at exploring the leadership and firm's perspective of the contemporary development of the smart city. This paper further suggests the need to conduct more research in the leadership attributes and activities in smart city leadership.
\end{abstract}

\author{
ARTICLE HISTORY \\ Received:11-11-2020 \\ Accepted:1-3-2020
}

KEYWORDS
Smart City
Leadership
Sustainability
Attributes
Activities

\section{KEYWORDS}

Leadership

Attributes

Activities

\section{INTRODUCTION}

In both literature and public policy, the notion of a smart city has been discussed in depth as city administrations and municipal governments attempt to keep their cities' living environment sustainable, safe, and resilient. Both parties also put the effort into increasing the quality of living for the cities' inhabitants through a suite of holistic smart services, which is a desirable value proposition. According to the United Nations (2018), it was projected that one in every three people will live in cities with at least half a million people in the future years. This growth helps drive many cities around the world to come together to discuss ways to renew existing infrastructure, develop new laws and introduce innovative and sustainable technologies (Chourabi, Nam, Walker, Gil-Garcia, Mellouli, Nahon, Pardo and Scholl, 2012; Cocchia, 2014; Snow, Håkonsson \& Obel, 2016; Toppeta, 2010). In recent years, many city mayors and government agencies around the world have championed the discourses on smart cities. Therefore, there is a mushrooming growth of many types of local and regional network alliances, industry groups, and trade organizations joining the discourse in smart city development. Some examples of such alliances are the Smart City Consortium in Hong Kong, the Knowledge Capital Association in Japan, and the Amsterdam Smart City Council. These alliances have been active in arranging thematic events on smart cities, conferences, overseas delegations, and publishing white papers to create public awareness. There is evidence of a growing body of literature covering smart cities and sustainable development in recent years. Öberg, Graham, and Hennelly (2017) however opined that most research carried out in this area are focused on the use of innovative technologies to enable smart cities or as a literature review of smart city policies at the societal level with very limited inferences to business management and leadership at large. As innovative technologies and new business sustainability policies are being promoted and implemented in our society, entrepreneurs and business leaders are becoming the driving force behind these non-profit alliance activities to promote smart city development. While some of these firms' leaders have demonstrated an interest to volunteer in these non-profit alliances, it is also important in exercising good leadership in the non-profit alliance. To excel as a leader of the alliance, it is also necessary to identify the type of leadership attributes and the type of activities organized and to investigate this play on the performance of the non-profit alliance performance. In this context, this paper presents the gaps in the current academic research and a proposed conceptual framework.

\section{LITERATURE REVIEW}

\section{The prominence of smart city alliance in Hong Kong and around the world}

In 2015, with the HKSAR government's plan to develop Hong Kong further to become a smart city, the private sector and many thought-leaders have also taken action to be involved at about the same time. There are many industry leaders, businesses, technology firms, and start-up company founders who are all keen to explore and learn about the policy development of HKSAR's smart city and to further look for future business opportunities arising from such government policy. In addition to business opportunities, many other professional organizations and subject-matter experts are also 
interested in contributing their expertise, experience, and time to educate and to advocate on the subject; particularly in promoting the need for information, communication, and technologies (ICT), and setting industry standards. Collectively, these industry leaders and subject-matter experts were initially working together as a self-interest group which continues to grow larger to become a special interest group. This newly formed special interest group has further garnered more mindshare and received the industry's support from a variety of business enterprises. This traction has led to an even more concerted effort from the founders (the original leadership team) to officially register the group as a non-profit organization called Smart City Consortium (SCC). SCC was subsequently inaugurated in May 2015 (SCC, 2020a) as a non-profit organization. In the context of academic literature, SCC could also be considered as an alliance (Grieco \& Iasevoli, 2017) with members consisting of firm companies from different sectors forming lateral collaboration and organizing, planning, and co-developing marketing activities together. Further to the notion of an alliance, SCC also plays the role of a business association (Marques, 2017) and trade association (Kahl, 2018) which is actively influencing and shaping the collective interests of their members in public policy.

Hong Kong is not the only city to have found this phenomenon of having an alliance formed and focusing on sustainability and smart city developments. There are also similar organizations formed as a non-profit alliance around the world. Through the SCC's outreach campaign and the leadership team's network, SCC has also developed many collaborative relationships with such smart city alliances in other countries. Therefore, it appears that such a phenomenon informing smart city alliances in recent years are not uncommon for Hong Kong. According to the President of SCC (G. Yeung, personal communication, July 24, 2020), SCC has signed many partnership MoU with these alliances to collaborate and explore inward or outward technology transfer or investment opportunities in promoting smart city development. Examples of such alliances are the Austrian Technology Corporation of Austria, the Smart City Development Alliance of China, the Smarter Bendigo of Australia, the Knowledge Capital of Japan, the Smart City Council of the United States, and the Smart City Alliance of Canada. These alliance organizations have all been active in arranging regular thematic events on smart cities, orchestrating overseas delegations, and publishing whitepapers to promote public awareness. It is also worth mentioning that even though face to face meetings, conference, business travels have been reduced significantly due to the recent Covid-19 pandemic situation happening around the world, it has not stopped the ongoing promotion and advocacy in smart city development. SCC, for example, was a partner organization in the Invest Hong Kong's Connected Cities Virtual Conference held on July 6 ${ }^{\text {th }}, 2020$ (KPMG, 2020) which had over 3,000 participants from around the world convening using online platform technologies.

\section{Alliance activities}

According to the SCC's $4^{\text {th }}$ annual general meeting held on 27 May 2020 (Figure 1), SCC now has 23 different committees and five special interest groups under the management with over 300 members. SCC has signed 36 memorandums of understanding (MoU) of partnerships with different local and overseas partners and it has also hosted or supported over 350 events (SCC, 2020b). All these activities are supported by the secretariat office, and projects are managed by different committees' chairperson. Each committee and special interest group is usually headed by a chairperson. The governance of the SCC is further managed by a board of council members, honorary members, treasurer, secretary, and technical advisors who collectively makes up the leadership team at the SCC.

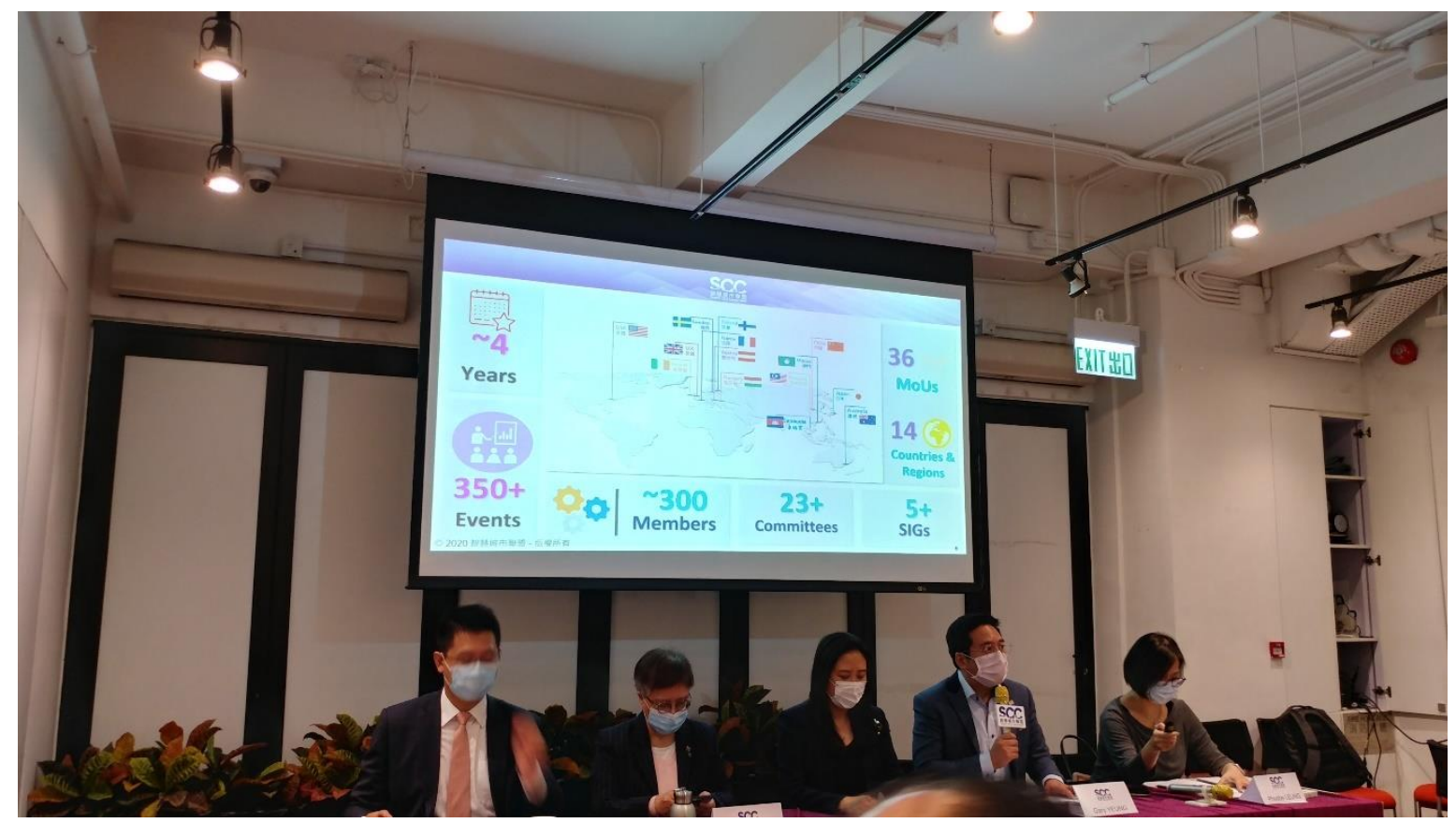

Figure 1. Smart City Consortium Annual General Meeting in Hong Kong (May 2020) 
Reviewing literature relating to the alliance, business association, and trade association, it shows that these types of non-profit organizations are also sometimes referred to as inter-organizational networks (Gulati, 1998; Gulati \& Gargiulo, 1999; Xia et al., 2018). The activities and mediating tools that these inter-organizational networks organized are often used to communicate with its community of stakeholders and future partners - speaking as one collective voice on matters and often pooling their resources (Marques, 2017) or enabling the continuous discourse as influencers of market cognition seeking legitimacy (Kahl, 2018).

A list of examples of these overseas alliances in which SCC has established a bilateral relationship through signing partnership MoU and their promotional activities are listed below. (see Table 1.).

In a recent interview with the president of SCC, (G Yeung, personal communications, July $24^{\text {th, }}$ 2020), the activities that SCC runs are often related to engagement of the entire community- connecting as a super hub for corporations, startup companies, academia, and the government to promote the smart city projects like "digital infrastructure such as electronic identity and common spatial data interfaces".

Table 1. Examples of smart city alliances and activities around the world

\begin{tabular}{|c|c|c|c|}
\hline Organization name & Countries & Type & Example of activities \\
\hline $\begin{array}{l}\text { Austrian Technology Corporation } \\
\text { (http://www.atc.or.at/) }\end{array}$ & Austria & Government & $\begin{array}{l}\text { Cyber-Security-Initiative } \\
\text { http://ilab.atc.gr/tags/cyber-security }\end{array}$ \\
\hline $\begin{array}{l}\text { Amsterdam Smart City Council } \\
\text { (http://amsterdamsmartcity.com) }\end{array}$ & Netherland & Government & $\begin{array}{l}\text { WeMakeThe.City } \\
\text { https://amsterdamsmartcity.com/events/we-make-the-city-- } \\
\text { opening-night-setting-the-urban-a }\end{array}$ \\
\hline $\begin{array}{l}\text { Iskandar Regional Development } \\
\text { Authority } \\
\text { (http://www.irda.com.my) }\end{array}$ & Malaysia & Government & $\begin{array}{l}\text { IRDA FIMAC forum } \\
\text { https://www.fimac.org/ }\end{array}$ \\
\hline $\begin{array}{l}\text { Knowledge Capital Association } \\
\text { (https://kc-i.jp/en/) }\end{array}$ & Japan & Industry & $\begin{array}{l}\text { Knowledge Innovation Award } \\
\text { https://kc-i.jp/activity/award/innovation/2017/ }\end{array}$ \\
\hline $\begin{array}{l}\text { Smarter Bendigo } \\
\text { (https://bebendigo.com.au/besmarter) }\end{array}$ & Australia & Industry & $\begin{array}{l}\text { Insight and Innovation Forum } \\
\text { https://bebendigo.com.au/be-inspired/bsbf18-event-brochure/ }\end{array}$ \\
\hline $\begin{array}{l}\text { Smart City Development Alliance } \\
\text { (http://www.ccud.org.cn/2014-05- } \\
\text { 06/114157470.html) }\end{array}$ & China & Industry & $\begin{array}{l}\text { 3rd China Smart City Innovation Conference } \\
\text { http://www.chinasmartcityexpo.com/ }\end{array}$ \\
\hline $\begin{array}{l}\text { Smart City Consortium } \\
\text { (http://www.smartcity.org) }\end{array}$ & HK & Industry & $\begin{array}{l}\text { Internet Economy Summit, Interim blueprint advisory report } \\
\text { https://smartcity.org.hk/images/eDM/docs/Advisory-Paper- } \\
\text { Interim-Report-2016-SCC.pdf } \\
\text { https://2017.ieconomysummit.hk/ }\end{array}$ \\
\hline $\begin{array}{l}\text { Smart City Council } \\
\text { (http://smartcitiescouncil.com) }\end{array}$ & USA & Industry & $\begin{array}{l}\text { Readiness Challenge } \\
\text { https://smartcitiescouncil.com/scc-2018-readiness-challenge-info }\end{array}$ \\
\hline $\begin{array}{l}\text { Smart Cities Alliance } \\
\text { (https://smartcityalliance.ca) }\end{array}$ & Canada & Industry & $\begin{array}{l}\text { Smart Cities Challenge } \\
\text { https://smartcityalliance.ca/initiatives/advocacy/national-smart- } \\
\text { cities-challenge-launched/ }\end{array}$ \\
\hline
\end{tabular}

Source: Self-developed, from Internet websites

\section{Leadership attributes}

In previous academic studies in leadership, it is generally agreed that leadership capabilities are essential for the success and growth of any organization (Conger, 2004; Koryak, Mole, Lockett, Hayton, Ucbasaran \& Hodgkinson, 2015; Sotarauta, 2016; Obiwuru et al., 2011; Suseno \& Ratten, 2007). However, it was also identified that leadership contexts in a traditional hierarchical organization and collaborative environment are different (Agranoff \& McGuire, 2001; Silvia, 2011). Others also provided the support that little was known whether the leaders of firms could effectively extend their leadership skills to manage an external network in collaborative situations (Vangen \& Huxham, 2003a; Morse, 2014). There is an apparent divergence in leadership theories for hierarchical entities and alliance type organizations where there are similarities in co-leadership, shared leadership, or lead as a collective (Bolden, 2011). Silvia (2011) posited that mainstream literature on leadership mostly focused on leaders in hierarchically structured entities in private sectors and hence, their leadership context will be significantly different from those of alliances. Huxham and Vangen (2000) also believe that leadership in the network environment could be more complex, more likely to be constrained and imposed upon by the alliance members' collective expectations and actions.

In the context of a non-profit alliance, where a private firm's leader is representing and volunteering at the alliance level, the work and activities carried out by the leader are by-design assuming fiduciary responsibilities (Kramer, 1999) with technical role competencies orchestrated to create impact for both the alliance firm and the member firms for which they represent. The expectations and agendas for the member firms and the alliance itself would have to be aligned to create the necessary recognizable impact and value (Agranoff \& McGuire, 2001; Zaheer \& Bell, 2005; Öberg et al., 2017). In addition to agenda alignment, leadership skills, traits, and competencies are therefore also important attributes when a leader is being selected to represent the alliance engaging in various mediating activities such as conferences and seminars and the alliance firm. It is therefore hypothesized that a great deal of the leadership attributes - skills, traits, and actions that are useful, practical, and embedded for the leaders in their firms may or may not be necessarily be matched with those in collaborative situations such as those required and practical for the alliance particularly in smart city developments (Öberg et al., 2017). McGuire and Silvia (2009) also previously pointed out that very few studies 
investigated leadership in network organization structure such as alliances especially for those alliances that are outside joint-venture or equity-based alliances. Öberg et al., (2017) further posited that having the right leadership attributes could help manage the expectations from the alliance leaders and member firms. As discussed earlier, Vangen and Huxham (2003a) highlighted from their research that leadership in collaborative situations will often require the leadership to engage in four progressive steps to move forward the agenda in such an alliance firm by embracing, empowering, involving, and mobilizing member firms. However, it was also highlighted that building trust and managing this key attribute in practice is critically important (Vangen \& Huxham, 2003b). In another seminal work in studying leadership attributes, O'Leary et al., (2012) also identified in their research study that personal attributes and interpersonal skills are important to engage member firms horizontally in networks and to bring multiple stakeholders to have a common consensus in the outcome.

A business leader who participated in a smart city alliance can maximize the gain from participating in alliance activities, especially when the business leader from a firm can extend his influence from within the company to the outside of the company. By representing the alliance, the leader's firm can orchestrate and engage in various alliance activities, such as conferences and seminars. A business leader with the right leadership traits and attributes can significantly enhance the reputation of the firm and the alliance that the leader is representing. However, there is a certain type of leaders that do better than others when exercising their leadership capabilities. Leadership skills, traits, and competencies are essential leadership attributes — an example of 59 leadership attributes by Gerstner and Day (1994) are summarized below (See Table 2).

Table 2. Leadership attributes (Gerstner and Day, 1994)

\begin{tabular}{|l|l|l|l|}
\hline Intelligent & Fair & Flexible & Forceful \\
Honest & Informed & Goal-oriented & Generous \\
Outgoing & Open-Minded & Good Administrator & Healthy \\
Understanding & Strict & Humanitarian & Kind \\
Verbal Skills & Strong Character & Insightful & Loyal \\
Aggressive & Unemotional & Interested & Minority \\
Determined & Athletic & Likable & Organized \\
Industrious & Believable & Persuasive & Outspoken \\
Caring & Charismatic & Strong Convictions & Patriotic \\
Decisive & Competitive & Unselfish & Responsible \\
Dedicated & Conservative & Wants Peace & Trustworthy \\
Educated & Concerned & Persistent & Tough \\
Well-Dressed & Cooperative & Manipulative & Strong \\
Authoritarian & Demanding & Courageous & Well-Groomed \\
Dishonest & Directing & Disciplined & \\
\hline
\end{tabular}

The great man theory (Carlyle, 1907) which could be traced back to iconic figure such as Napoleon had always hypothesized that certain leaders are "born to lead" and these leaders possess several unique characteristics and qualities - which is further considered as trait-like differences or state-like differences and explained how leaders can perform differently in a different context (Hoffman, Woehr, Maldagen-Youngjohn \& Lyons, 2011).

It was further suggested by Nam and Pardo (2011) that the notion of collaborative leadership and cross-organization management are the important elements in determining the success and performance of smart city development projects and they further posited that:

"Leadership is not only exercised for a single agency, department, or team but extending to a network and enterprise of organizations. This does not suggest that central leadership is unimportant, but notably ICT-driven organizational, structural changes such as network encourage coordination among diverse actors rather than hierarchical command and control. Thus, leaders should develop their network leadership skills."

According to the literature review presented, there is a gap in the literature related to researching leadership in nonprofit alliance context especially in smart city development. With the ongoing development of smart cities around the world, it presents an opportunity for researchers to investigate what smart city alliances (and generic non-profit alliance firms) should recruit when it comes to their leadership team - perhaps assessing their leadership attributes and also understanding what type activities they can manage and lead, which would make a positive impact and bring better performance in the non-profit alliance. The next section will present our conceptual framework for conducting such a research topic.

\section{THE SMART CITY LEADERSHIP CONCEPTUAL FRAMEWORK}

In this conceptual paper, a theoretical framework is proposed by borrowing the theoretical framework of the firstgeneration Activity Theory (Vygotsky, 1978). Adopting this model of activity-based approach involved analyzing the styles of the individual (the leader's attributes) as the subject in an alliance firm that is mediated through a range of tools and artifacts (i.e. activities, events) and evaluating the objective (i.e. alliance performance). In the first generation of activity theory proposed by Vygotsky (1978), he suggested that an individual who is leading an organization as in a new 
business venture would need to account for various activities that bridge the subject-object dualism. In activity theory, it consists of a subject and an object (similar to goals and outcomes) and for the current subject to achieve a certain object (outcome), this subject (could be an individual or a group) will need to be engaged in an activity using mediating artifacts (a series of tools and devices) as shown below in Figure 2. The figure shows how mediating artifacts (as in tools) could be used to help achieve the object.

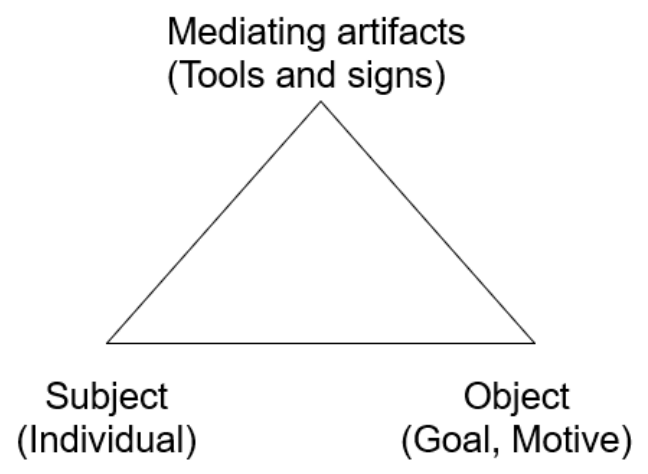

Figure 2. Activity system (Vygotsky, 1978)

In other words, this activity is therefore undertaken by a subject using tools to achieve an objective. This first generation of activity theory (sometimes referred to as an activity system) by Vygotsky (1978) was further expanded and developed by Engeström (2014) where he argued that the activities should take place in situations (situated) with a specific context. Engeström (2014) further elaborated this simple and original activity theory to also be included as a collective activity with participation from a community (comprising of different people or actors sharing the same object), the relationships amongst these actors and their interactions are governed by a clear set of rules which regulates their actions and interactions. According to Jones and Holt (2008), this activity theory framework helped analyze the organization activities that situates the leader within the collective contexts of the new businesses and organizations.

In a series of leadership research led by Vangen and Winchester (2014), the conceptualization of leadership issues is often rooted in collaborative situations, which extends from traditional hierarchical relationships around formal business settings, to focus on collaborative activities that could lead to definitive outcomes. Vangen and Winchester (2014) argued that a collaboration's structure (much like an alliance firm) and its communication processes (much like activities) are leadership media (tools and mediating tools) that are important in driving the collaboration to reach some outcomes (See Figure 3).

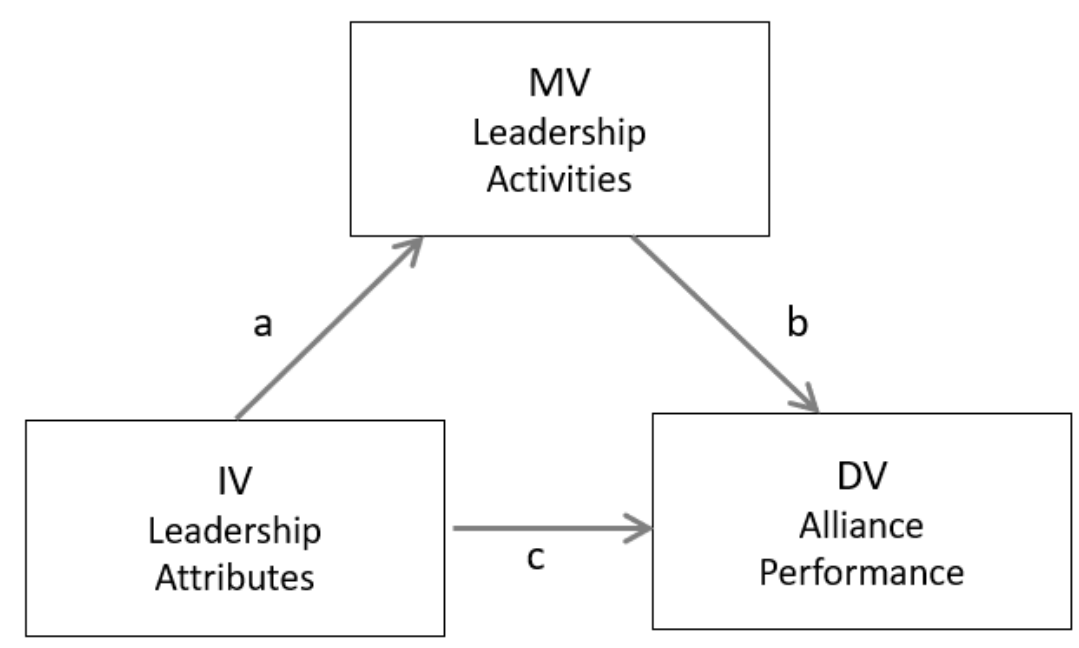

Figure 3. The smart city leadership conceptual framework

The use of activity theory as the theoretical framework in the research of smart city alliance helps provide a better understanding of how leaders (with different leadership attributes) engaged themselves in numerous business activities as a collective for the alliance firm involved in smart city development. Activity theory is also generally used by educational and social science researchers to study work practices, organization learning, cognition, and human activities (Kuutti, 1999). Kuutti (1999) however also suggested that as the activity theory is also multi-disciplinary, and it begins 
with the assumptions that many human activities are culturally, historically, and socially produced, it is therefore suitable for researching human activities and organizations. Vygotsky (1978) and Engeström (2014) are some of the leading researchers in the development of these theories. This perception of a leader's attributes and activities by stakeholders is one of the important outcomes of the organizational performance in academic research (Khan, Hafeez, Rizvi, Hasnain, \& Mariam, 2012) but is less well understood in the smart city context.

\section{DISCUSSION}

As introduced earlier, the discourse of smart city developments is increasingly popular, and many activities related to smart city development have been promoted by industry alliances which are in turn led by industry leaders to advance the discourses through organizing activities. Therefore, alliances promoting these activities require good organizational management and leadership. Referring to the literature review, it is found that there is evidence that very few academic studies have been conducted to investigate leadership theories and organizational behavior with a focus on the smart city context, and even fewer leadership studies have been investigating the organizational management in smart city developments. The extent to which members of an alliance contribute in harnessing the resources of the alliance equally depends on how well the leaders of the alliance adopt appropriate leadership style (attributes) in performing their duties when organizing various activities (Khan et al., 2012).

In his extensive literature review, Öberg et al. (2017) revealed that most of the current research studies in the smart city have been focusing on either reporting the application of innovative technologies to enable smart cities or in the form of a comparative review of smart city frameworks and policies at the societal level. One recent effort initiated by the University of Birmingham with four case studies of smart city projects of different scales, however, offered some preliminary findings suggesting some specific implications on smart city leadership. For example, the researchers believed the following traits and attributes are essential - a blend of leadership experience in private, public, and third sector; a sound understanding of technology and digital expertise; conversant in social literacy and possess a relational worldview; has a long-range foresight for impact and the willingness to support bottom-up innovations, knowledge management, team engagement and social inclusion (Birmingham University, 2019).

Future research study can be directed to focus on determining the extent to which member firm's leadership attributes and alliance activities would lead to better performance for an alliance involved in smart city developments. The following section will describe the research questions guided by this research objective. With a focus on Hong Kong's smart city development, the research objective of future study by the authors will be to explore the roles of leadership attributes and activities in influencing alliance performance. In particular, future data collection will attempt to identify specific leadership attributes and the different types of activities displayed by active member firm leaders that show influence on their alliance performance in the smart city development.

\section{Smart leadership role in the alliance}

When a business leader assumes a position in an alliance, there is also a need to take the lead to collaborate with other stakeholders or members of the alliance to organize various activities (seminars and conferences) to create public awareness. Without such activities, neither the alliance nor the member firms will be able to benefit from the social networking opportunities and business insights shared by industry experts and government officials. There are some correlations to the success of such activities and leadership attributes which in return produce better achievements of the alliance goals and objectives in promoting the smart city and sustainability development.

Business leaders are known to take the lead in joining or even forming trade associations and often take up voluntary leadership positions. These voluntary positions give the business leaders the authority and fiscal budget to help set the agenda in trade practices and to lobby or influence public policy and the industry ecosystem. This behavior conforms to the desire for firms to explore the external network to increase its ability for acquiring external knowledge and learn as a community - information benefits (Porter, 1998). Besides gaining information benefits, business leaders joining an alliance could help their firm to experience accelerated growth in the rate of innovation and revenue growth. Furthermore, when a firm's leader is representing and volunteering at the alliance level, the work and activities carried out by the leader are by-design assuming fiduciary responsibilities (Kramer, 1999) with technical role competencies orchestrated to create impact for both the alliance firm and the member firms for which they represent. This view is also supported by the recommendation from Höpfl, Baker, Kan, and Teo (2011) pinpointing the need for leadership to be active at multiple levels.

\section{CONCLUSION}

Smart city development creates great opportunities for industry advancement, a better quality of life, and new businesses. This topic is widely discussed in recent scholarly literature, business forums, and conferences. Take an example of one of the website called SmartCitiesWorld.net that promotes smart city development (Smart Cities World, 2018), which published an article titled Smart leaders for Smart City Success and offered some suggestions for smart city leadership which includes servant leadership, achieving a balance between innovation and sustainability, and cultivating strategic thinking and foresight. In particular, the author specifically believes smart leadership: - 
“...facilitates collaboration, uses strategic thinking, practices foresight activities, builds alliances and partnerships, gets out of the office and into the trenches where things are not cozy, welcomes and integrates a diversity of thought, and is, foremost, a servant."

In addition to the growing awareness of the notion of smart cities and sustainability, it is also observed that many government-led and industry-led alliances are beginning to take the stage to champion the development and discourses. In a nascent industry as multi-disciplinary as the smart city value proposition, it calls for a new level of leadership. Gibney, Copeland, and Murie (2009) already provided the arguments to support that a new level of strategic leadership is much needed for crossing boundary and network towards a more fluid relational process to achieve the objectives of the organization to influence urban policymakers and collaborators in creating better-managed cities and economies.

Smart city development often requires business leaders to face new frontiers and volunteer to take up leadership positions in various industry alliances. These leaders are expected to be proactive in engaging different stakeholders and ultimately advancing the objectives of the alliance. Among these objectives include business opportunity's creation, the innovative technologies development and alliance's reputation, and trust-building activities. The importance of having the right leadership attributes and organizing various leadership activities can ensure the performance of the alliance firm and the leaders' business. Furthermore, the expectations and agendas for the member firms and the alliance itself would have to be aligned to create the necessary recognizable impact and value (Agranoff and McGuire, 2001; Zaheer and Bell, 2005; Öberg et al., 2017). Leadership skills, traits, and competencies are important leadership attributes when a leader represents the alliance engaging in various mediating activities such as conferences and seminars and the alliance firm. It is therefore hypothesized that a great deal of the leadership attributes - skills, traits, and actions that are useful, practical, and embedded for the leaders in their firms may not be necessarily be matched with those in collaborative situations such as those required and practical for the alliance particularly in smart city developments (Öberg et al., 2017).

Smart city projects around the world are becoming increasingly popular in policymaking, urban planning, technology innovations, health care, and delivering city municipal services. This multi-disciplinary orientation of smart city is also suggesting that there will be many different areas for which new technologies and new legislation could be applied to deliver the results, and this often requires a consistent level of advocacy effort and campaigns to create public awareness and education for all the stakeholders. Accordingly, the implementation of smart city initiatives and various associated advocacy campaigns will have to be led by capable managers and leaders. It is in this context that this paper proposes a conceptual framework that intends to investigate the leadership attributes, the activities, and the performance of the alliance, and further research study will be able to follow this framework for researching leadership in smart city development. In conclusion, leadership and cross-organization management are essential elements in determining the alliance performance of smart city development. The leadership should be exercised and extended to a network of entities through collaborations and building the so-called "social infrastructure" for multiple organizations to join and collaborate as an alliance. Specific alliance activities and specific leadership attributes are to be studied further for assessing the relationship of these vis-à-vis the alliance performance in achieving its social mission and objectives in promoting smart city development.

\section{REFERENCES}

Agranoff, R., \& McGuire, M. (2001). Big questions in public network management research. Journal of public administration research and theory, 11(3), 295-326.

Birmingham University, 2019. Smart Leadership for Smart Cities. Retrieved from

https://www.birmingham.ac.uk/Documents/college-social-sciences/business/research/smart-cities-project.pdf on Apr 20, 2020.

Bolden, R. (2011). Distributed leadership in organizations: A review of theory and research. International Journal of Management Reviews, 13(3), 251-269.

Carlyle, T. (1907). On heroes, hero-worship, and the heroic in history. Boston, MA: Houghton Mifflin.

Chourabi, H., Nam, T., Walker, S., Gil-Garcia, J. R., Mellouli, S., Nahon, K., ... \& Scholl, H. J. (2012, January). Understanding smart cities: An integrative framework. In System Science (HICSS), 2012 45th Hawaii International Conference on (pp. 2289-2297). IEEE.

Cocchia, A. (2014). Smart and digital city: A systematic literature review. In Smart city (pp. 13-43). Springer International Publishing.

Conger, J. A. (2004). Developing leadership capability: What's inside the black box? The Academy of Management Executive, 18(3), 136-139.

Engeström, Y. (2014). Learning by Expanding: An Activity-Theoretical Approach to Developmental Research. Cambridge University Press.

Gerstner, C.R., and Day, D.V., 1994. Cross-cultural comparison of leadership prototypes. The Leadership Quarterly, 5(2), pp.121-134.

Gibney, J., Copeland, S., \& Murie, A. (2009). Toward a new strategic leadership of place for the knowledge-based economy. Leadership, 5(1), 5-23.

Grieco, C., \& Iasevoli, G. (2017). Co-marketing alliances: definitions and approaches. Insights from a literature review. Management Research Review, 40(9), 971-989.

Gulati, R. (1998). Alliances and networks. Strategic management journal, 19(4), 293-317.

Gulati, R., \& Gargiulo, M. (1999). Where do interorganizational networks come from? American journal of sociology, 104(5), 14391493. 
Hoffman, B. J., Woehr, D. J., Maldagen-Youngjohn, R., \& Lyons, B. D. (2011). Great man or great myth? A quantitative review of the relationship between individual differences and leader effectiveness. Journal of Occupational and Organizational Psychology, 84(2), 347-381.

Höpfl, H., Baker, E., Kan, M. and Teo, S.T., 2011. Developing a collaborative network organization: leadership challenges at multiple levels. Journal of Organizational Change Management, 24(6), pp. 853-875.

Huxham, C., \& Vangen, S. (2000). Leadership in the shaping and implementation of collaboration agendas: How things happen in a (not quite) joined-up world. Academy of Management journal, 43(6), 1159-1175.

Jones, O., \& Holt, R. (2008). The creation and evolution of new business ventures: an activity theory perspective. Journal of small business and enterprise development, 15(1), 51-73.

Kahl, S. J. (2018). The role of trade associations in market discourse and cognition. Journal of Management Inquiry, 27(1), 13-15

Khan, V., Hafeez, M., Rizvi, S., Hasnain H, \& Mariam, A. (2012). Relationship of leadership styles, employees' commitment and organization performance: A study on customer support representatives. European Journal of Economics, Finance and Administrative Sciences, 49 (1) 133-43.

Koryak, O., Mole, K. F., Lockett, A., Hayton, J. C., Ucbasaran, D., \& Hodgkinson, G. P. (2015). Entrepreneurial leadership, capabilities and firm growth. International Small Business Journal, 33(1), 89-105.

Kramer, R. M. (1999). Trust and distrust in organizations: Emerging perspectives, enduring questions. Annual review of psychology, 50(1), 569-598.

Kuutti, K. (1999). Activity Theory, Transformation of Work, and Information Systems Design. Perspectives on activity theory, 360374.

KPMG (2020), Connected Cities Conference. Retrieved at https://home.kpmg/cn/en/home/events/2020/07/the-connected-citiesconference.html

Marques, J. C. (2017). Industry business associations: self-interested or socially conscious? Journal of Business Ethics, 143(4), 733751.

McGuire, M. and Silvia, C., 2009. Does leadership in networks matter? Examining the effect of leadership behaviors on managers' perceptions of network effectiveness. Public Performance \& Management Review, 33(1), pp.34-62.

Morse, R. S. (2014). Developing public leaders in an age of collaborative governance. In Innovations in public leadership development (pp. 91-112). Routledge.

Nam, T., \& Pardo, T. A. (2011, September). Smart city as urban innovation: Focusing on management, policy, and context. In Proceedings of the 5th international conference on theory and practice of electronic governance (pp. 185-194).

Öberg, C., Graham, G. and Hennelly, P., 2017. Smart cities. IMP Journal.

Obiwuru, T. C., Okwu, A. T., Akpa, V. O., \& Nwankwere, I. A. (2011). Effects of leadership style on organizational performance: A survey of selected small-scale enterprises in Ikosi-Ketu council development area of Lagos State, Nigeria. Australian journal of business and management research, 1(7), 100.

O’Leary, R., \& Vij, N. (2012). Collaborative public management: Where have we been and where are we going? The American Review of Public Administration, 42(5), 507-522.

Porter, M. E. (1998). Clusters and the new economics of competition (Vol. 76, No. 6, pp. 77-90). Boston: Harvard Business Review.

SCC. (2020a), website retrieved from https://www.Smartcity.org.hk

SCC. (2020b), annual general meeting held on May 27, 2020. Retrieved from https://smartcity.org.hk/en/events-photodetail.php?id=116

Silvia, C. (2011). Collaborative governance concepts for successful network leadership. State and local government review, 43(1), 6671.

SmartCitiesWorld (2018) Smart leadership for smart city success. Retrieved from https://www.smartcitiesworld.net/opinions/opinions/smart-leadership-for-smart-city-success or Retrieved from https://www.lugosantiagoeg.com/smart-leadership-for-smart-city-success/

Snow, C. C., Håkonsson, D. D., \& Obel, B. (2016). A smart city is a collaborative community: Lessons from Smart Aarhus. California Management Review, 59(1), 92-108.

Sotarauta, M. (2016). Shared leadership and dynamic capabilities in regional development. In Regionalism Contested (pp. 63-82). Routledge.

Suseno, Y., \& Ratten, V. (2007). A theoretical framework of alliance performance: The role of trust, social capital and knowledge development. Journal of Management \& Organization,13(1),423.

Toppeta, D. (2010). The Smart City Vision: How Innovation and ICT Can Build Smart. Livable, "Sustainable Cities. The Innovation Knowledge Foundation" (http://www. thinkinnovation.org/file/research/23/en/Toppeta_Report_005_2010.pdf).

United Nations (2018). The World Cities in 2018. Retrieved from the Internet from https://www.un.org/en/events/citiesday/assets/pdf/the_worlds_cities_in_2018_data_booklet.pdf

Xia, J., Wang, Y., Lin, Y., Yang, H., \& Li, S. (2018). Alliance formation in the midst of market and network: Insights from resource dependence and network perspectives. Journal of Management, 44(5), 1899-1925.

Vangen, S., \& Huxham, C. (2003a). Enacting leadership for collaborative advantage: Dilemmas of ideology and pragmatism in the activities of partnership managers. British Journal of Management, 14, S61-S76.

Vangen, S., \& Huxham, C. (2003b). Nurturing collaborative relations: Building trust in interorganizational collaboration. The Journal of Applied Behavioral Science, 39(1), 5-31.

Vangen, S., \& Winchester, N. (2014). Managing cultural diversity in collaborations: A focus on management tensions. Public Management Review, 16(5), 686-707.

Vygotsky, L. (1978). Interaction between learning and development. Readings on the development of children, 23(3), 34-41.

Zaheer, A., \& Bell, G. G. (2005). Benefiting from network position: firm capabilities, structural holes, and performance. Strategic management journal, 26(9), 809-825.

\section{ACKNOWLEDGEMENT}

The authors would like to express their sincere gratitude to the Hong Kong Smart City Consortium for supporting this research project. 


\section{AUTHORS' BIOGRAPHY}

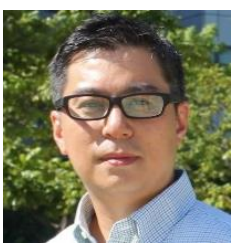

Daniel Chun Jung Yue is a PhD candidate at the Graduate School of Business at the Universiti Sains Malaysia and is the Vice-President (Elect) and Chairman of Research and Blueprint Committee at Hong Kong's Smart City Consortium.

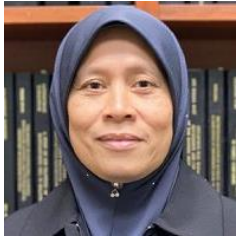

Dr. Nabsiah Abdul Wahid is currently a Professor at the Graduate School of Business at the Universiti Sains Malaysia.

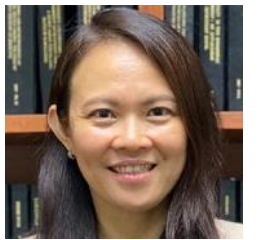

Dr. Tan Cheng Ling is currently an Associate Professor at the Graduate School of Business at the Universiti Sains Malaysia. 